\title{
Extraction, Exploitation and Degradation: A Brief Environmental History of Western Investment in Jamaica Thomas McCarthy
}

Tom McCarthy is pursuing a degree in History and Environmental Studies. He is interested in examining the intersections between people, their histories, and the environment, while attempting to form these into wider critiques of oppressive economic and social systems. In addition to his studies, he organizes with University of Toronto Environmental Action, a student group focused on climate justice for youth. Upon graduation, he's looking forward to political activism, hopefully some travel outside of North America, and eventually a return to postgraduate studies.

Hurricanes are nothing new to Jamaicans; they have been a part of the seasons for as long as people have lived there. While they are often devastating and traumatic, people have always somehow managed to pick up the pieces, sweep up the damage, and move on with their lives. However, as severe weather events associated with climate change become more frequent and intense, and climatic conditions at large become less compatible with status quo environmental and agricultural practices, Jamaica is woefully unprepared to weather the storms of the 21st century. Due to a complex and interrelating set of historical factors, Jamaica's natural defenses against severe weather have been consistently degraded and undermined in the name of profit and development.

From its start as a Spanish, then English colony, through centuries of slavery and sugarcane monoculture; to its twentiethcentury resource extraction and tourism-based economy, Jamaica's people and natural assets have been exploited and abused to an enormous degree. However, through it all, persistent outside influences have limited and affected the choices available to the country's leaders, particularly following independence. The same widespread practices and industries that have harmed Jamaica's environment, like sugar, bananas, and bauxite, have been lucrative to those who controlled them. The work of economists like George Beckford supports the notion that the underdevelopment of Jamaica is a dynamic process stemming from the legacy of slavery and continuing through to the present. People and the environment often serve as a mirror to each other; what is beneficial for society in a collective and holistic sense tends to be good for the environment, 
and vice versa. In the case of the Caribbean, as Anderson contends, "the ecosystem of all small islands has a turbulent history, the same turbulence to which environmental institutions help us adapt. As a result of these disruptions, the biological and social-cultural systems become intertwined."

By outlining the historical narrative of Jamaica's development from an environmental perspective, it becomes clear how the very same economic ideology and practices that have contributed to poverty, exploitation, and strife in Jamaica today have degraded its natural systems to the point that life there may become untenable in decades to come barring significant change. The dominance of socially and environmentally-intensive practices and the outflow of resources and capital are fundamental features of all four of Jamaica's major historical industries; sugar, bananas, bauxite, and tourism.

When Europeans first arrived in Jamaica, and indeed the Caribbean in general, they were taken aback at the natural beauty and abundance of the island and its surrounding seas. However, the reason they had stumbled upon these islands in the first place was because they had been dispatched by the courts of Europe to find a route to Asia, and in turn its goods and spices. They arrived seeking profit, and though they failed to find India, they were not disappointed with the wealth-generating potential of islands like Jamaica. Though the Spanish were the first to conquer Jamaica and through the enslavement of the indigenous population, exploit the region, it was the English who fully implemented and institutionalized a plantation economy in Jamaica following their capture of the island in 1655 .

As George Beckford and Michael Witter trace in Small Garden, Bitter Weed, when English settlers first brought highquality sugarcane from Barbados, they found that it thrived in Jamaican soil. However, sugarcane production, especially at a large scale, was very labour-intensive. At the same time, to pay Englishmen wages to perform this truly hard labour was not

${ }^{1}$ Robert S. Anderson, "Gardens and Forests on Caribbean Islands: Two Hundred Years of Environmental Institutions," in Islands, Forests and Gardens in the Caribbean: Conservation and Conflict in Environmental History. Ed. Robert S. Anderson et al., (Oxford, Macmillan Education/Warwick University, 2006), 11. 
economically feasible, or rather not optimal for maximum profits. ${ }^{2}$ The English and other colonizing powers solved this problem by utilizing enslaved African to make their plantations profitable. Early plantation owners were quick to capitalize on this opportunity.

The establishment of the Royal Africa Company in the 1670 s represents England's entry as a major power in the Trans-Atlantic slave trade. Over the next two centuries, millions of Africans were captured and brought to Jamaica to work in the cane fields. ${ }^{3}$ As African peoples were dehumanized and oppressed, the sugarcane continued to grow in vast and expanding plantations. Other enterprising slave owners made investments in coffee, ginger, spices, and other valuable commodities, growing and slightly diversifying Jamaica's plantation economy.

As the cane was sowed, forests were felled, and swamps were drained and filled in. Canals for irrigation were dug, and streams were dammed. Large inland areas of Jamaica were transformed from rich, diverse tropical forest and grasslands to fields of uniform crops. Sugarcane itself is a very intensive plant to grow at large scale; each plant requires a large quantity of water and nutrients in order to grow. Like other high-calorie crops, if grown on the same plot of land for several years, the quality of the soil is greatly reduced. Additionally, the English planters who controlled and directed this agricultural development were unfamiliar with the environmental dynamics of tropical ecosystems. In apparent contradiction to the lush forests that grow on them, tropical soils are in fact fairly poor for growing crops, but when one thinks about these forests from a different perspective, it is clear that most of the nutrients lie in the vegetation above ground. The detritus of organic matter that covers the ground of any healthy forest is what provides the minerals and nutrients to plants, not the sandy soil underneath.

When a forest is removed, this loose top layer of rich organic matter is easily and quickly eroded. Watts refers to the prevailing

\footnotetext{
2 George Beckford and Michael Witter, Small Garden, Bitter Weed (Morant Bay: Maroon Publishing House,1980), 17.

3 ibid.
} 
attitudes towards cane cultivation and land use as "dangerously simplistic views of the nature of cane land soils in the [Caribbean]."4 Over time, as cane yields gradually declined, planters found ways to mitigate soil erosion and nutrient loss, such as an increase in manure fertilization, sourcing timber from South America rather than island forests to reduce erosion, and notably the practice of planting cane in depressed plots known as cane holes.

To give an impression of the human toll of this practice, Watts notes that slave gangs of about 50 members were commonly expected to excavate one acre of land roughly two meters deep on every day in the planting season, which amounts to an absurd amount of digging. Most of these practices had been innovated in the Windward and Leeward Islands, and came to use in Jamaica in the early to mid-1700s. ${ }^{5}$ Regardless of their effectiveness in mitigating environmental degradation, the nutrient-taxing nature of large-scale cane production remained the same, as did the requirement to cut down forests and import slaves to feed the hunger for increased profit.

As Europe's demand for sugar grew, so did the size of the plantations. Planters who were unable to succeed were forced to sell their land to more profitable plantations, contributing to the rise of a class of extremely wealthy and powerful planters. However, as Beckford and Witter write, "The slave mode [of production] was totally dependent on the English market: it was supplied with inputs from English factories and in turn sold its output to English consumers ... thus the reproduction of slave society from year to year depended on its relations with English capitalism, [which] expanded on the surpluses thus extracted from slave production." 6 In conjunction, "from the end of the 17th century on, sugar production [in Jamaica] survived under the protection of tariffs levied on sugar produced outside the English colonial empire." 7 This is important to note, because of the nature of dependency it describes. As Jamaica progressed, the nature of this economically dependent relationship with powerful nations would change, but remain largely in place. Ultimately, the environmental legacy of the plantation economy in

4 David Watts, The West Indies: Patterns of Development, Cultural, and Environmental Change Since 1492. (Great Britain: Cambridge University Press, 1987), 396.

5 ibid.

${ }^{6}$ Beckford and Witter, Small Garden, Bitter Weed, 17.

7 Beckford and Witter, Small Garden, Bitter Weed, 21. 
Jamaica runs parallel to its social legacy: the natural environment was exploited to the largest degree possible consistent with sustained profits for the ruling class. Wealth and resources mostly flowed out of the country to England and throughout the empire, and what wealth remained was concentrated in the hands of the few at the expense of the many.

When slavery was formally abolished across the British Empire in 1838, it was mainly due to the fact that plantation economies where no longer profitable. Resistance movements from enslaved populations, pressure from an ascendant industrial class who viewed plantations as inefficient and costly, (chafed at the cost of staple foodstuffs needed to feed their workers inflated by tariffs and subsidies for the colonies)and the abolitionist movements in British empire all contributed to emancipation. However, as Beckford and Witter point out, emancipation was hollow for many Jamaicans, who were forced to sell their labour for wages, often to their former masters. "The strategy was to formally emancipate the slaves but deny them real freedom by ensuring that the means of production, particularly land, remained in the hands of European capitalists." 8

However, as much as land use had been dominated by sugarcane cultivation, a peasant land base had developed alongside it to provide food and other important crops and services. Many former slaves were involved in this economy, but more rushed to join it following emancipation. It was a key to self-sufficiency, and with it, freedom. Those who could provide for themselves off of the land were able to avoid the predations of the plantation system. As Besson writes, "freed slaves, wherever they could, sought to obtain freehold land ... those who managed to obtain freehold land transformed this into family land to ensure freehold rights to all their descendants in perpetuity. As land was denied to the slave, so was kinship; and family land is also the basis on which kin groups or family lines are created and kinship maximized."9 Although discussing Haiti, Laurent Dubois sheds some light on this mindset: "on these small

\footnotetext{
8 Beckford and Witter, Small Garden, Bitter Weed, 22.

9 Jean Besson (1984): Land tenure in the free villages of Trelawny, Jamaica: A case study in the

Caribbean peasant response to emancipation, Slavery \& Abolition: A Journal of Slave and Post-Slave

Studies, 5:1, 3-23
} 
farms, [freed slaves] did all the things that had been denied to them under slavery: they built families, practiced their religion, and worked for themselves." 10

This type of agriculture led to a very different relationship between people and the land. These people depended on the land for not only subsistence, but for maintaining and protecting their autonomy, and such ties to the land naturally lead to a strong respect for it. To live off the land requires a deep understanding of the interrelating forces of nature, and an appreciation for the ecosystems that provide means for human survival.

For roughly a century, these two economies existed alongside each other. As Beckford argues in Persistent Poverty, the plantation model continued to be a major organizational influence on the development of the Jamaican economy. However, an essential component to understanding the change in Jamaica's development at the turn of the century lies in the development of wealthy countries. As Beckford writes, "By the 2oth century economic maturity had arrived in the metropolitan countries, and business corporations there were ready for direct overseas investment." 11 Essentially, having gorged itself on profits gained through centuries of exploitation and subjugation, the West had a surplus of capital and was looking for ways to invest and grow it.

An illustrative example of this in Jamaica is the case of the banana industry. As the global balance of power shifted from the British Empire to the United States of America, particularly in the areas claimed by the Monroe Doctrine, American corporations began to take interest in Jamaica. In the 19th century, bananas had been a household crop on many plots of family land. Bananas are nutritious, grow on a tree (thereby leaving space below for other crops), and are quite delicious. Technological changes like faster ships and refrigeration made it feasible to transport perishable goods from the tropics to markets in America and Europe, and tropical fruit production was seen as a profitable investment. The United Fruit Company of the United States came to Jamaica to capitalize on this. Beckford and Witter elaborate on this, arguing that the development of the Jamaican banana industry was crucial in several ways. It broke

10 Laurent Dubois, Haiti: The Aftershocks of History, (New York: Metropolitan Books, 2012), 6.

11 George Beckford, Persistent Poverty, (Mona, Jamaica: UWI Press, 1972$), 85$. 
the monopoly of sugar over the island's economy and well-being, but simultaneously reinforced its 'original export orientation.' 12 Additionally, it was much more amenable to small-scale production than sugar and far less labour-intensive, which allowed for peasants to actually make some revenue off their land. At first, this benefited the peasant economy, but as more and more took the opportunity to make money off of bananas, the large landowners and companies like United Fruit came to dominate much of Jamaica's prime agricultural land. And like the plantation owners, their principal concern was profit. Beckford and Witter comment: "Together with sugar, banana production for export ... dominated the peasant sector, which was increasingly marginalized and made to function as its labour reserve." ${ }^{13}$ People who thought they were getting a good deal selling their banana produce to the big companies and their middle-men soon realized they had been effectively corralled into a wage-based economy. Many at this time chose to emigrate, thereby selling their land to the highest bidder, who unsurprisingly would likely use the land to grow more bananas.

The most obvious environmental impact of this dominance is blanket monoculture: as huge swaths of the Jamaican countryside devoted to the cultivation of a single plant. Beyond the economic risks associated with over-reliance on few commodities, this had the impact of further harming and reducing biodiversity, which is absolutely essential for healthy and resilient ecosystems. Also, because bananas could be cultivated on hillsides, there was a push to deforest many inclined tracts of land that had previously been left relatively undisturbed. When heavy rains come, banana trees planted in uniform rows are no match for healthy forest in terms of preventing and mitigating erosion and gullying. Additionally, the banana industry had the affect of wresting many people from the peasant economy, which was the only sector of the economy that approached what is termed sustainable today. People who can provide for themselves, a lack of opportunity and resources aside, often have a far greater degree of autonomy than wage-earners, and are undoubtedly a less taxing and frequently beneficial presence for their local environments. Due to the various institutions that structure this dependent relationship to the land, they are invested in keeping it healthy and productive, and to do so means being attentive to and defensive of the small details that make ecosystems

12 George Beckford and Michael Witter, Small Garden, Bitter Weed, 50.

13 George Beckford and Michael Witter, Small Garden, Bitter Weed, 51. 
function; from pollinating insects that are integral to food production, to songbirds that keep pests at bay.

Today, fertilizers and pesticides are sprayed in large quantities on Jamaica's remaining banana and cane field, which is associated with a host of terrestrial pollution concerns, but is particularly damaging to the coastal environment. As it runs off and flows into the ocean, fertilizers contribute to coral-smothering algae blooms, and pesticides and antibiotic effluents harm a wide range of species.

Additionally, Beckford and Witter mention how in times of scarcity, particularly when the global economy collapsed during the Great Depression, peasants were able to furnish organic consumer products from their natural surroundings, such as soap and cooking oil from coconuts, and flour from dried and ground cassava. ${ }^{14}$ Today people in rich countries pay top dollar for such organic products; they are undeniably more compatible with the goal of sustainability and are superior from a human health perspective to synthetic and mass-produced consumer products. With the banana trade came the beginnings of tourism, with a few entrepreneurs installing luxurious passenger quarters on their banana boats to ferry wealthy North Americans and Europeans to tropical getaways. As the consolidation, expansion, and dominance of the banana trade shows, "the basic pattern of socio-economic relations and institutions had already been determined by sugar." 15 By 1960, on the eve of independence, 300 estates of over 500 acres occupied 40 percent of Jamaica's arable land.16 While the twentieth century progressed, this overall trend would continue to define Jamaica's economic development.

Following the Second World War, there was a massive demand for lightweight metals, most significantly, aluminum. This metal alloy was a cheap and durable building material, and was used for all sorts of postwar consumer products, from radios to toaster ovens, as well as being essential for the booming airplane industry. Aluminum is derived from the naturally occurring ore bauxite, of which Jamaica was once incredibly rich.

14 George Beckford and Michael Witter, Small Garden, Bitter Weed, 65.

15 ibid.

16 George Beckford, Persistent Poverty, 242. 
In 1962, Jamaica gained its independence from Great Britain. But, like emancipation over a century before, this failed to transform the exploitative and stratified organization of Jamaican society. Due to a lack of political imagination, the young country's new leaders were faced with the dilemma of meeting social needs while maintaining positive economic growth. Because of the booming demand for aluminum, one of the first actions of the governing pro-market Jamaican Labour Party (JLP) was to allow heavy foreign investment in the country's resource sector, taking cues from Puerto Rico's 'Operation Bootstrap.' This came in the form of allowing five major multinational corporations to buy up nearly all of Jamaica's bauxite resources; four American, and one Canadian. ${ }^{17}$ Within five years, Jamaica was the world's largest supplier of the ore, producing $21 \%$ of global supply. ${ }^{18}$ As Bradley notes, "Just as it had under colonial rule, a few top-ranking civil servants and company directors were doing very well, as were a rapidly increasing number of overseas-based multinational corporations, but other than that, this new money meant nothing except on paper." Continuing their analysis, Beckford and Witter argue that despite diversification, "post-war developments reinforced the basic import-export orientation of the economy." 19

Bauxite mining was hugely degrading for inland Jamaica, particularly in the eastern mountains. As Coke, Weir, and Hill outline, "Impacts of mining and processing on environmental quality have been evident both in the long and short term. The landscape has been damaged, [and] valuable agricultural soils have been replaced by badly eroded skeletal soils capable of sustaining only grass production." 20 Clear-cutting a patch of forest and tearing up the earth beneath has completely destroyed whatever ecosystem once existed. But beyond denuding large tracts of rural Jamaica, the processing of the bauxite ore produces much pollution. And even though they are drastically inferior to native forest, monoculture banana tree farms are far better than a scraped-up moonscape in terms of preventing erosion. Jamaica has one of the world's highest

17 George Beckford and Michael Witter, Small Garden, Bitter Weed, 67.

18 Lloyd Bradley, Bass Culture: When Reggae Was King, (London: Penguin Books, 2001), 263.

19 George Beckford and Michael Witter, Small Garden, Bitter Weed, 66.

20 Coke, Weir, and Hill, "Environmental Impact of Bauxite Mining and Processing in Jamaica," Social and Economic Studies: 36 (1987) 289-333. 
rates of deforestation. ${ }^{21}$ For a nation that experiences heavy rains seasonally, this is highly problematic. Any pollution left in the soil is carried off by erosion into both streams and groundwater used for drinking supplies. Although it provided the country with breakneck 7\% annual GDP growth for a period and helped address unemployment, nearly all of that wealth flowed out of the country and into the accounts of the five major multinationals that had been allowed to dominate the industry. By the time Michael Manley's People's National Party was prepared to implement reforms that would keep some of the revenue in Jamaica in the mid-1970s, much of the island's bauxite had already been extracted. ${ }^{22}$

The exploitation of bauxite resources occurred simultaneously with the explosion of the tourism industry. In the midst of post-war North America's towering affluence, unprecedented numbers of everyday people could afford to spend a week or two on a beach in the Caribbean. As in many neighbouring countries, tourism has become a fundamental sector of Jamaica's economy, bringing in an estimated $\$ 944$ billion in revenue in 2008. ${ }^{23}$ However, this has had extremely significant impacts on the island's natural defenses against severe weather.

Natural features such as coral reefs, wetlands, salt ponds, hillside forests, and mangrove swamps are essential to sustainable human settlement in Jamaica. Coral reefs and mangrove forests provide a barrier against strong waves and storm surge; wetlands soak up and filter torrential rains while hillside vegetation holds the soil firm and prevents mudslides. Moreover, these ecosystems provide essential services for people who rely on the land and sea-for example, the same reefs, mangroves, and wetlands that protect the island from storms provide necessary habitats for fish reproduction, which local fisherman in turn rely on to feed themselves and make a living.

21 Tony Weis, "Beyond peasant deforestation: environment and development in rural Jamaica," Global Environmental Change: 10(2000) 4, 299-305.

22 William Jesse Biddle and John D. Stephens, "Dependent Development and Foreign Policy: The Case of Jamaica," International Studies Quarterly: 33 (1989) 4, 411-434.

23 “Vision 2030 Jamaica: Tourism Sector Plan, 2009-2030," Tourism Task Force, Gov't. of Jamaica, 2009. 
However, coral reefs, wetlands, and mangroves are not what the tourists come to see. The popular imagination of the Caribbean in the West is of palm trees and cocktails with miniature umbrellas on pristine white beaches that stretch out endlessly over a sandy, turquoise sea. It's what office workers in cold, wintery climes like Minneapolis and Toronto save up for months to visit, and what wealthy people across North America and Europe are accustomed to. Unfortunately, while this type of setting exists naturally in many parts of Jamaica, in many others, coral reefs abound. Corals may be vibrant and colourful when filmed with an underwater HD camera, but from the shore they look like dark grey patches interrupting the turquoise expanse. Additionally, they are full of sharp corals and all sorts of creatures that do not take kindly to being molested or stepped on by unsuspecting tourists, like lobsters, or sea urchins. Therefore, hotel developers are keen to get rid of them. Additionally, a combination of poverty and greed has led some shortsighted fishermen to use dynamite to increase their catches. ${ }^{24}$

Although Jamaica has land-use laws comparable to many other countries based on the British legal system, hotel developers often operate under lax regulatory oversight and foster environmentally degrading and socially exclusive zones along much of Jamaica's coast. In Last Resorts: The Cost of Tourism in the Caribbean, Polly Pattullo characterizes the negative environmental context of hotel development and tourism as the region's second invasion of 'land-snatchers': "...in the past half-century, it has been the coastline which has been cleared- for however much the Europeans admired the Caribbean paradise, they could not resist claiming it and 'improving' it." 25 While this may sound strident, it is no overstatement. Places that had once been used by local fisherman and which hosted crucial nesting and hatchery sites for fish, birds, and reptiles have been wholly transformed to meet the demands of tourism. As Jerome plainly states, "Small, ecologically fragile islands have restructured their colonial export staple economies towards

\footnotetext{
24 Thomas J. Goreau, "Coral Reef Protection in Western Jamaica," Protecting Jamaica's Coral Reefs:

Water Quality Issues, 1992, 39-65.

25 Polly Pattullo, Last Resorts: the Cost of Tourism in the Caribbean, (London, Latin America Bureau, 2005),130.
} 
tourism by establishing transformational infrastructure and largescale resort complexes along delicate coastlines." ${ }^{26}$

Pattullo minces no words when discussing how countries, like Jamaica, are "locked into a chain of tourist development where short-term gain takes precedence over long-term protection." 27 Take the town of Ocho Rios. The name means 'Eight Rivers,' so naturally one would expect marshes and wetlands close to where these eight rivers meet the sea. However, because of the pressures of tourism development, much of these endemic wetlands have been drained, filled in, and built upon. For example, 40 acres of wetlands were recently turned into a 4,00o bed resort complete with a cruise ship pier. ${ }^{28}$ Long channels of coastal sea floor must be dredged to accommodate large cruise ships, which in turn pollute the water with their exhaust and waste. Developers cut down stands of coastal palm trees to improve the view from hotel rooms only to find that the beach erodes even faster without roots holding the sand together. In turn, the sand is drawn out by the tides, and chokes already beleaguered coral reef and sea grass ecosystems. In order to furnish tailor-made resort environments, sand from less developed areas is mined in large quantities and transported elsewhere. Considering that due to a host of factors stemming from human action an estimated 90 percent of coral reefs worldwide are damaged, it is essential that remaining reefs be safeguarded if humans are to continue to benefit from them. ${ }^{29}$

Socially, the tourism industry has had a largely negative impact on working-class Jamaicans, who are left with little option but to find jobs in hotels, as tour-guides, or as other ancillary participants in the tourism economy. Using the justification that their resorts are all inclusive, many resorts are closed off to ordinary Jamaicans, who are charged exorbitant prices to walk along and make use of the beaches where they once caught crabs as children or stored their boats during hurricane season..$^{30}$ Altogether, tourism has been environmentally and socially degrading to Jamaica, and while it

\footnotetext{
${ }^{26}$ McElroy Jerome, Island Tourism: A Development Strategy for Biodiversity, INSULA Magazine, 2001.

27 Polly Pattullo, Last Resorts: the Cost of Tourism in the Caribbean, 132.

28 Polly Pattullo, Last Resorts: the Cost of Tourism in the Caribbean, 131.

29 ibid.

30 Marie Dixon Frisch, "Victory at Pear Tree Bottom," Greening Politics: 33 (2007) 1.
} 
differs significantly from sugarcane, bananas, and bauxite, most of the revenue still flows to foreign bank accounts.

One decade into the 21st century, these four major industries have left Jamaica with a fragile, tenuous, and heavily damaged environment. Much of the island's natural defenses against severe weather have been destroyed or greatly reduced. Additonally, Jamaica is situated in one of the most hurricane-prone places in the world. People recall storms like 1988's Hurricane Gilbert, remembered in the famous Lovindeer song 'Wild Gilbert,' with a mix of resignation and apprehension. It was the second most powerful hurricane ever recorded in the western hemisphere, and left 45 dead and 400,000 homeless over the next several weeks, and caused heavy damage to an estimated $20 \%$ of structures on the island. ${ }^{31}{ }^{32}$ As the climate heats up, the warm-water conditions which create and fuel hurricanes are going to become increasingly powerful. Jamaicans can expect for storms like Gilbert, which have always been once-in-a-generation events, to occur with a steadily increasing severity and frequency barring massive, global action to halt climate change. It is especially cruel that countries like the United States, Canada, and Great Britain, who have plundered Jamaica for centuries and benefitted so much from its exploitation, are the ones most directly responsible for the carbon emissions driving climate change. All this paints an incredibly bleak environmental future for Jamaica, which must urgently reform the way it allows foreign businesses to operate on its territory, start massive efforts to reverse environmental damage and allow ecosystems to heal, and begin to make the sweeping adaptations required to help its people weather the intensified storms of the 21st century.

31 Lovindeer, Wild Gilbert, 1988.

32 Philip R. Berke and Timothy Beatley, After The Hurricane (Baltimore: Johns Hopinks Press, 1988), 55. 